University of Nebraska - Lincoln

DigitalCommons@University of Nebraska - Lincoln

Faculty Publications from the Harold W. Manter Laboratory of Parasitology

6-1976

Neodeuterobaris pritchardae gen. et sp. n. (Digenea:

Microscaphidiidae) in a Sideneck Turtle, Podocnemis lewyana

Dumeril 1852, from Colombia

Daniel R. Brooks

University of Toronto,dnlbrooks@gmail.com

Follow this and additional works at: https://digitalcommons.unl.edu/parasitologyfacpubs

Part of the Parasitology Commons

Brooks, Daniel R., "Neodeuterobaris pritchardae gen. et sp. n. (Digenea: Microscaphidiidae) in a Sideneck Turtle, Podocnemis lewyana Dumeril 1852, from Colombia" (1976). Faculty Publications from the Harold W. Manter Laboratory of Parasitology. 215.

https://digitalcommons.unl.edu/parasitologyfacpubs/215

This Article is brought to you for free and open access by the Parasitology, Harold W. Manter Laboratory of at DigitalCommons@University of Nebraska - Lincoln. It has been accepted for inclusion in Faculty Publications from the Harold W. Manter Laboratory of Parasitology by an authorized administrator of DigitalCommons@University of Nebraska - Lincoln. 


\title{
NEODEUTEROBARIS PRITCHARDAE GEN. ET SP. N. (DIGENEA: MICROSCAPHIDIIDAE) IN A SIDENECK TURTLE, PODOCNEMIS LEWYANA DUMERIL 1852, FROM COLOMBIA*
}

\author{
Daniel R. Brooks \\ Gulf Coast Research Laboratory, Parasitology Section, Ocean Springs, Mississippi 39564
}

ABSTRACT: Neodeuterobaris pritchardae in the stomach of the freshwater turtle, Podocnemis lewyana, from Colombia resembles members of Deuterobaris in possessing ventral glands, a dorsal oral hood, and vitelline follicles confluent posteriorly, but apparently differs from them by possessing 5 rather than 7 rows of ventral glands; by lacking ventral spines, extracecal uterine loops, and a muscular esophageal bulb; and by inhabiting the stomach of freshwater turtles rather than the intestine of marine turtles. Those characters are considered significant enough to erect a new genus. Diagnosis of the Deuterobaridinae is emended to accommodate the new species.

This report describes a new species of digenean belonging to the family Microscaphidiidae Travassos 1922 found in the stomach of Podocnemis lewyana Dumeril 1852 (Chelonia: Pelomedusidae) in Colombia. The genus Podocnemis Wagler is composed of seven species of sideneck turtles found in South America and one species found in Madagascar. Digeneans have prevously been reported for five of the South American species: P. expansa (Schweigger) (8 spp.), P. cayennensis (Schweigger $)(=P$. erythrocephala and $P$. tracaxa) (3 spp.), $P$. unifilis (Troschel) (2 spp.), $P$. dumeriliana (Schweigger) (1 sp.), and $P$. vogli (Müller) (1 sp.).

Three specimens of Podocnemis lewyana were collected at night with the aid of a throw net and headlamp from the Quebrada Doña Juana in the vicinity of La Dorada, Caldas, Colombia, and examined within $12 \mathrm{hr}$. Five specimens of the digenean were found in the stomach of one turtle. They were examined live with the aid of a stereoscope, then flattened with slight coverslip pressure, fixed with AFA, and stored in 70\% ethanol. All were stained with Mayer's hematoxylin. Four were mounted in Canada balsam for study as whole mounts. The fifth was retained as an alcoholic specimen for study of the ventral glands, which are not visible in the whole mounts. Host specimens are in the Kansas University $\mathrm{Mu}-$ seum. All measurements are in micrometers

Received for publication 12 November 1975 .

* Funds for this study were provided through a grant from the National Geographic Society to Dr. Thomas B. Thorson, University of Nebraska. unless otherwise stated; figures were drawn with the aid of a drawing tube.

\section{Deuterobaridinae Looss 1902 Emended}

Diagnosis: Body oval, with or without 2 posterior projections of the body, with or without spines on ventral surface, with longitudinal rows of ventral glands. Dorsal cephalic lobe containing oral sucker projecting over dorsal body surface. Oral diverticula present or lacking. Muscular esophageal bulb at posterior end of esophagus present or absent. Ceca terminating near posterior end of body. Testes tandem or oblique, in middle third of body. Cirrus sac absent. Ejaculatory duct short, straight, tubular. Pars prostatica relatively short. Metraterm shorter or longer than pars prostatica. Genital pore ventral to esophagus. Ovary posttesticular. Vitellaria follicular; follicles extracecal and intercecal in posterior half of body, confluent near cecal tips. Lymphatic system accompanying ceca, branched at periphery of body. Excretory system with V-shaped vesicle. Parasites in stomach and intestine of marine and freshwater turtles.

Type genus: Deuterobaris Looss 1902.

Other genus:

\section{Neodeuterobaris gen. $n$.}

Diagnosis: Deuterobaridinae. Aspinose. Ventral glands in 5 longitudinal rows. Oral diverticula present. Esophageal bulb absent. Uterus without extracecal loops. Vitelline follicles in 2 paired groups; anterior pair extracecal, posterior pair near cecal tips. Parasites in stomach of freshwater turtles.

Type and only species:

\section{Neodeuterobaris pritchardae sp. n.}

(Figs. 1-6)

Description (based on 4 mounted and 1 unmounted stained specimens ): Body elongate, extremely muscular, 3.08 to $4.18 \mathrm{~mm}$ long by 1.79 to $2.02 \mathrm{~mm}$ wide; with 2 weakly developed pro- 

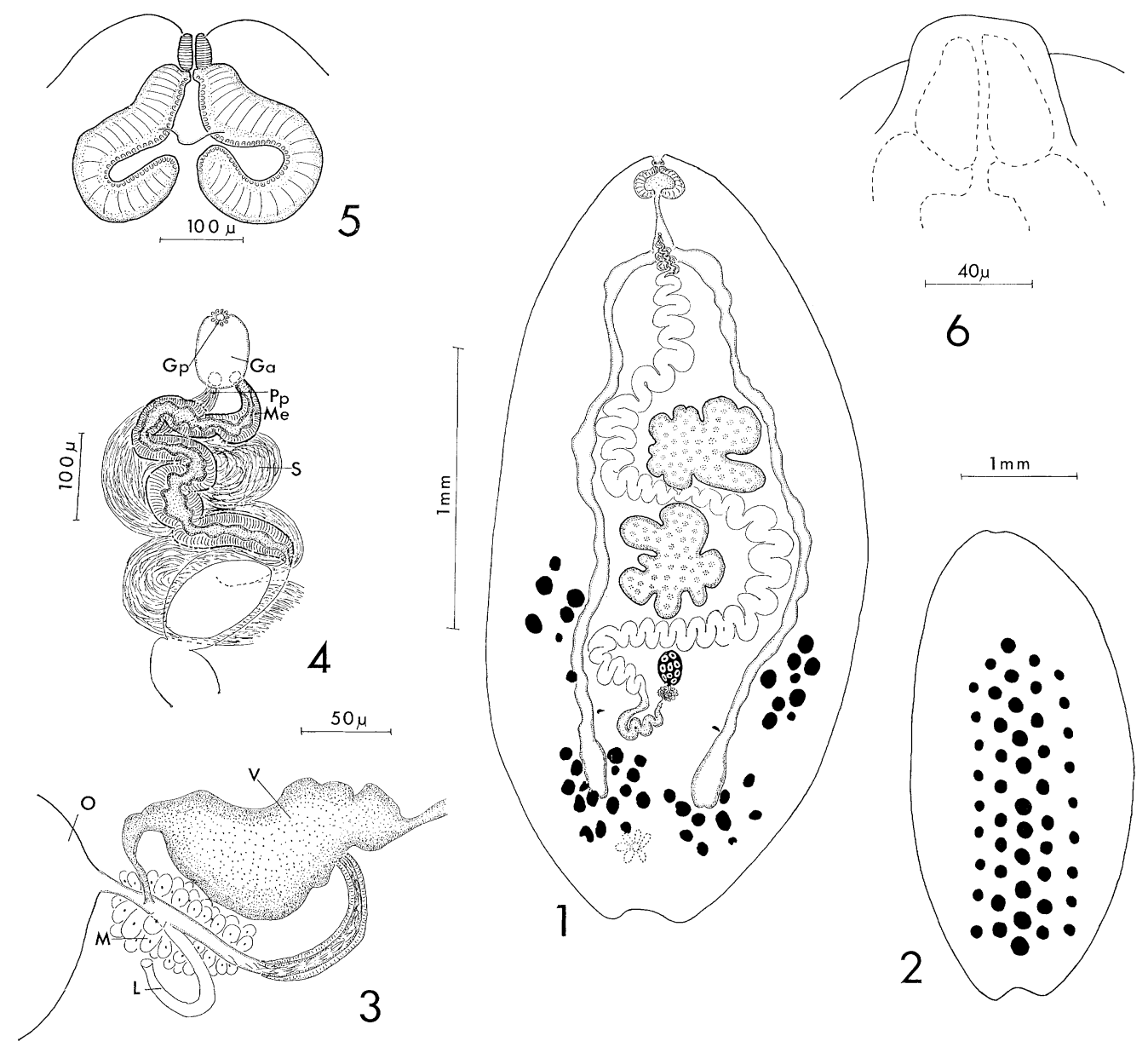

Figures 1-6. Neodeuterobaris pritchardae, from a sideneck turtle from Colombia. 1. Holotype, ventral view. 2. Ventral glands of unmounted specimen. 3. Ootype, dorsal view. 4. Terminal genitalia, ventral view. 5. Oral sucker, ventral view. 6. Oral hood, dorsal view. Legend: Ga, genital atrium; Gp, genital pore; L, Laurer's canal; M, Mehlis' gland; Me, metraterm; O, ovary; Pp, pars prostatica; $\mathrm{S}$, seminal vesicle; $\mathrm{V}$, vitelline receptacle.

jections at posterior end. Ventral glands in posterior $3 / 4$ of ventral surface. Oral sucker terminal, protrusible, 28 to 48 long by 36 to 48 wide; diverticula large, glandular, 192 to 216 long by 240 to 300 wide; walls muscular. Esophagus 144 to 280 long, dilated at intestinal bifurcation; bifurcation $1 / 4$ body length from anterior end. Ceca sinuous, extending to within 13 to $15 \%$ body length of posterior end. Testes intercecal, tandem to slightly oblique, deeply lobed; anterior testis 466 to 564 long by 600 to 640 wide, posterior testis 384 to 660 long by 552 to 708 wide; anterior testis 15 to $19 \%$ body length from bifurcation. Seminal vesicle saccate, winding, 400 to 500 long; pars prostatica extremely short. Genital pore ventral to esophagus, $1 / 3$ distance from bifurcation to oral sucker. Genital atrium simple, 80 to 100 long. Metraterm ventral to and as long as seminal vesicle. Uterus coiled, extending posteriorly between testes and slightly postovarian, recurving to ootype. Ovary posttesticular, median, 132 to 193 long by 132 to 156 wide, 28 to $35 \%$ body length from posterior end of body. Ootype immediately postovarian; uterine seminal receptacle present; Laurer's canal and Mehlis' gland present. Extracecal pair of vitelline follicles extend to midline of posterior testis, posterior pair confluent at cecal tips. Vitelline receptacle dorsolateral to ootype. Eggs 138 to 149 long by 58 to 92 wide. Excretory pore dorsal, postcecal; excretory plexus present. Lymphatic system composed of 2 pairs of tubules accompanying ceca.

Host: Podocnemis lewyana.

Site: Stomach.

Locality: Quebrada Doña Juana, vic. La Dorada, Caldas, Colombia. 
Holotype: USNM Helm. Coll. No. 73486.

Paratypes: USNM Helm. Coll. No. 73487; Univ. Neb. State Mus., H. W. Manter Lab. No. 20249.

The species is named in honor of Mary Hanson Pritchard, curator of the Harold W. Manter Laboratory of Parasitology, in recognition of her contributions to digenean taxonomy.

\section{DISCUSSION}

Brandes (1891) described Monostomum proteus from Chelone virdis L. (= Chelonia mydas L.) from an undisclosed locality; Looss (1902) erected the genus Deuterobaris and subfamily Deuterobaridinae for it, characterized by the presence of oral diverticula, spination on the ventral body surface and ventral glands. Neodeuterobaris pritchardae resembles Deuterobaris more closely than any other microscaphidiid genus since it possesses ventral glands, a dorsal oral hood, and vitelline follicles confluent posteriorly. It differs in having two projections of the posterior end of the body and five rather than seven rows of ventral glands; by lacking ventral spines, extracecal uterine loops, and an esophageal bulb; and by inhabiting the stomach of a freshwater turtle rather than the intestine of a marine turtle.

Gupta (1961) described Deuterobaris chelonei from Chelone mydas (= Chelonia m.) from Trinidad, placing it in the genus without discussing the presence of ventral glands, or the absence of oral diverticula. No type specimens were designated, nor was any record of deposition of type material given in the publication. I have tried unsuccessfully to obtain specimens from the Canadian National $\mathrm{Mu}$ seum and from Dr. S. P. Gupta.

Yamaguti (1971) gave an expanded diagnosis of the Deuterobaridinae, listing Deuterobaris proteus and $D$. chelone $i$ as its only members, but his diagnosis clearly excludes the latter species. Despite an incomplete knowledge of $D$. chelonei, I believe the species should be retained in the subfamily at the present time. Accordingly, with the description of $N$. pritchardae, the subfamily diagnosis has been emended to include all species presently associated with it.
Of the 14 species of digeneans known to parasitize species of Podocnemis, seven belong in the superfamily Paramphistomoidea (Stiles and Goldberger 1910) Yamaguti 1971: five in the Paramphistomidae Fischoeder 1901 and two in the Microscaphidiidae Travassos 1922. Podocnemitrema papillosum Alho and Vicente 1964, the only microscaphidiid besides Neodeuterobaris pritchardae known from freshwater turtles in South America, was described from the stomach of Podocnemis expansa from Brazil (Alho and Vicente 1964). Despite sharing the same genus of host and site of infection, $P$. papillosum differs greatly from $N$. pritchardae since it has an oral sucker sunken into the anterior portion of the body which communicates with the exterior through a tube, no ventral glands, testes extending extracecally, and vitelline follicles not confluent posteriorly.

\section{ACKNOWLEDGMENTS}

The author appreciates the assistance of Dr. John D. Lynch, University of Nebraska, for host identifications; Dr. Rita O'Clair, Curator of Invertebrates of the Canadian National Museum, for her aid in attempting to find specimens of Deuterobaris chelonei; and Dr. Robin M. Overstreet, Gulf Coast Research Laboratory, for his aid in the preparation of this manuscript.

\section{LITERATURE CITED}

Alho, C. J. R., And J. J. Vicente. 1964. Podocnemitrema papillosus ( $\mathrm{sic}$ ) n.g., n. sp. e nova organizaçao da familia Microscaphidiidae Travassos 1922 (Paramphistor:oidea). Rev Bras Biol 24: 17-24.

Brandes, G. P. H. 1891. Die Familie der Holostomiden. Zool Jahrb 5: 549-640.

Gupta, S. P. 1961. On some trematodes from the intestine of the marine turtle, Chelone mydas, from the Caribbean Sea. Can J Zool 39: 293-298.

Looss, A. 1902. Ueber neue und bekannte Trematoden aus Schildkröten, nebst Erörterungen zur Systematik und Nomenclatur. Zool Jahrb 16: 411-898.

YamaguTI, S. 1971. Synopsis of Digenetic Trematodes of Vertebrates. Vols. I and II. Keigaku Publ. Co., Tokyo, 1074 p. 